\title{
Língua e meio ambiente
}

\author{
Language and environment
}

\section{Hildo Honório do Couto Universidade de Brasília}

\section{Abstract}

Although the first reflexions on the inter-relationships between language and its environment go back to at least Heraclitus and Plato's Cratylus, in modern linguistcs they have not received the attention they deserve. One notable exception is the German dialectological school known as "Wörter und Sachen". In the 20 and Haugen touched on them. However, it was only in the last decade of the last Century that a discipline specifically dedicated to them appeared, namely ecolinguistics. The main purpose of this article is to show that there are at least four environments of language, i. e., the Fundamental Environment of Language, which is subdivided in the Social, the Mental and the Natural Environment of Language. Some subjects that can be investigated within each of them are suggested. It is shown that there are two ways of approaching the inter-relationships between language and the world. The first places language between us and the world. This means that we only have access to it via language. The second places us between language and the world, what implies that language is created by us to interact not only with one another but also with the environment itself. In accordance with modern science, the new approach to language sees it in a network of inter-relationships, not in isolation as do the Cartesian and the Newtonian models. A good point of departure for this new approach is ecology, related to the science of life, biology. In this new viewpoint, each specialist can study his/her special domain without forgetting that it is part of a whole (ecosystem), with its diversity and the inter-ralationships that obtain within it. 


\section{Keywords}

Language; environment; society; nature; mind; inter-relationships; modern science.

\section{Resumo}

Embora as primeiras reflexões sobre as inter-relações entre língua e meio ambiente recuem a pelo menos Heráclito e ao Crátilo de Platão, elas não rêm recebido a atenção que merecem na linguística moderna. Uma das poucas exceções é a escola dialetológica alemã conhecida como "Wörter und Sachen". No século XX, Edward Sapir e Einar Haugen também tocaram no assunto, mas foi só na última década do século passado que surgiu uma disciplina dedicada especificamente a esse tipo de inter-relações, ou seja, a ecolinguística. O principal objetivo deste artigo é mostrar que há pelo menos quatro meios ambientes da língua, quais sejam, o ecossistema fundamental da língua, subdividido em três outros, que são os ecossistemas social, mental e natural da língua. Alguns dos principais assuntos que podem ser abordados dessa perspectiva são sugeridos. Entre outras coisas, vê-se que há duas maneiras de atacá-lo. A primeira localiza a língua entre nós e o mundo, o que significa que só temos acesso a ele por meio dela. A segunda nos vê entre o mundo e a língua, o que implica que ela é criada por nós para interagirmos não somente uns com os outros, mas também com o próprio meio ambiente. Em sintonia com a ciência moderna, a nova abordagem vê a língua como fazendo parte de uma teia de inter-relações, não isolada como nos modelos de Descartes e de Newton. Uma fonte adequada de onde se podem tirar conceitos para erigir as suas bases epistemológicas é a ecologia, parte da biologia, a ciência da vida. Na nova visão de mundo, cada especialista pode se dedicar ao seu domínio específico, mas não se esquecendo de que ele faz parte de um todo maior (ecossistema), com sua diversidade interna e as inter-relações que aí se dão.

\section{Palavras-chave}

Língua; meio ambiente; sociedade; natureza; mente; inter-relações; ciência moderna. 


\section{Introdução}

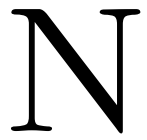

o âmbito da filosofia, o tema "língua e meio ambiente" tem sido explorado desde a Antiguidade, mesmo que sob a forma de relação entre palavra e coisa. Basta lembrar o famoso debate entre os naturalistas (phýsis) e os convencionalistas (nómos ou thésis), tão bem representados por Crátilo, de um lado, e Hermógenes, de outro, no Crátilo de Platão. Antes, a tese da phýsis já fora defendida por Heráclito e a da thésis por Demócrito. Os naturalistas defendiam uma influência das coisas designadas nas palavras que as denotam. Os convencionalistas defendiam a tese oposta, de que a linguagem é puramente resultado de uma convenção, não havendo nenhuma influência do designatum no designans. Na linguística, o tema não é muito popular. É raro encontrarmos algum pronunciamento sobre ele. Uma das poucas exceções é a escola dialetológica Wörter und Sachen, que enfatizava a abordagem onomasiológica diante da semasiológica.

Devido à consciência que pelo menos alguns segmentos da sociedade estão tendo sobre a crescente degradação do meio ambiente em que vivemos, pareceu-me de bom alvitre retomar o tema sobre as relações entre língua e mundo, no contexto da linguística, sob nova luz. Devo adiantar, porém, que a tônica do artigo não será o movimento ambientalista, mas literalmente "as relações entre língua e meio ambiente", doravante MA. Esse movimento é apenas uma das facetas da complexidade que são essas relações.

Na linguística, um dos primeiros, e raros, autores a tratar das relações entre língua (L) e MA de modo explícito foi Edward Sapir (1888-1939). Em 28 de dezembro de 1911, ele pronunciou uma conferência sob o título "Language and environment", naAssociação Antropológica Americana. O texto saiu no American anthropologist (v. 14, p. 226-242, 1912) e, posteriormente, nos Selected Writings of Edward Sapir in language, culture and personality (cf. MANDELBAUM, 1949).Em 1969, Joaquim Mattoso Câmara Jr. traduziu o texto e o incluiu na coletânea Sapir (1969), sob o título de "Língua e ambiente", talvez pelo fato de a expressão 
"meio ambiente" ainda não ser muito popular na década de sessenta. Poderíamos mencionar também a sociolinguística moderna, que relaciona a língua a um, e só a um, dos possíveis meios ambientes a que ela está interligada. Na década de setenta, Einar Haugen retomou a ideia, sob os rótulos de "environment of language" e "language environment", como em Haugen (1972), cujo objetivo era justamente relacionar L e MA social. Esses dois autores podem ser considerados como pioneiros na área em questão.

O objetivo deste artigo é retomar o tema discutido pioneiramente por Sapir e Haugen, no âmbito da linguística, incorporando descobertas ulteriores bem como mostrando os novos modos de encarar as relações entre língua e MA que têm sido desvelados recentemente por alguns investigadores, sobretudo europeus. Na ecologia, MA é parte de um ecossistema, no seio do qual a língua se relaciona com a população que a fala e com o território em que essa população vive. Esse ecossistema é o que veio a ser chamado de ecossistema fundamental da língua enquanto o MAda língua em seu interior é o MAfundamental da língua. Veremos também que esse ecossistema se decompõe em três subecossistemas: social, mental e natural. No interior de cada um deles, a língua tem um MA, ou seja, MA social, MA mental e MA natural da língua, respectivamente. O ecossistema maior será estudado na seção imediatamente seguinte. Os subecossistemas que o compõem serão examinados nas seções 3, 4 e 5, respectivamente. A seção 6 retomará as relações entre L e MA. O foco dessa seção é a autonomia relativa que a língua adquire vis-à-vis mundo, o que tem levado alguns estudiosos a pensar, erradamente, que é L que cria o mundo. Na seção 7, apresento a nova disciplina ecolinguística, antevista por Haugen, em 1972, e Hagège (1985, p. 328), além de Salzinger (1979), o primeiro a utilizar o nome "ecolinguística" e dar algumas amostras de quais seriam as suas tarefas. Por fim, temos as Considerações Finais, na seção 8 .

\section{Ecossistema Fundamental da Língua}

Para o leigo, o italiano é a língua dos italianos, que habitam a Itália; o grego, a língua dos gregos, que residem na Grécia; o russo, a língua dos russos, que se encontram na Rússia. Na Europa já me foi perguntado se eu falava "brasileiro". Na França, especificamente, podem-se ver livros com a seguinte informação: "traduit de l'américain" (traduzido do [inglês] americano). A ideia subjacente a 
tudo isso é a de que cada povo habita um território próprio, falando sua própria língua. Dito de outro modo, cada território $(\mathrm{T})$ é ocupado por um povo $(\mathrm{P})$, que tem uma língua $(\mathrm{L})$ específica. Frequentemente, Té denominado com base no nome do povo que o habita. É o que indica o sufixo -ia de Itália, Grécia e Rússia, que significa algo como "terra dos...", no caso, "terra dos italianos ou ítalos, dos gregos e dos russos", respectivamente. O morfema germânico -land (terra), que é uma tradução do "ia-" latino, é mais convincente ainda: Deutschland (Alemanha) é a terra (land) dos Deutsche (alemães), England (<Angland) é a terra dos anglos, Finlândia é a terra dos finos e assim por diante. Aqui não há espaço para entrar em pormenores, mas, se pensarmos em grupos étnicos (como os ameríndios), praticamente todos eles estão nesse caso. Eles provavelmente são reminiscências de uma situação prototípica, original, na qual vigia o princípio um território, um povo, uma língua. Essa concepção laica coincide com a possível situação prototípica. Para entendê-la, é necessário partir do conceito de ecossistema (cf. COUTO, 2007, p. 24-38).

Ecossistema é um conceito da ecologia biológica. Ele pode ser definido como sendo "o conjunto vivo formado pela biocenose (comunidade biológica) e pelo biótopo (fatores físicos e químicos do ambiente) em interação" (AMABIS \& MARTHO, 1995, p. 333). Em termos menos técnicos, ecossistema é o sistema formado pela interação dos membros de uma comunidade de organismos com seu meio ambiente e deles entre si. Como já mostrara o pioneiro Arthur Tansley, quem delimita o ecossistema a ser estudado é o próprio investigador. Com isso, ecossistema "pode ir do universo como um todo até o átomo" (TANSLEY, 1935). Essa característica nos ajuda inclusive a entender a espinhosa questão das fronteiras entre as línguas, problema que os primeiros dialetólogos já haviam percebido, embora não tivessem podido resolvê-lo, uma vez que não tinham as ferramentas teóricas adequadas. É preciso ressaltar também que, dentro de um ecossistema, o que interessa não são os seres ou organismos em si, mas as interrelações que se dão entre eles e o MA, bem como deles uns com os outros. A língua emerge dessas inter-relações, sobretudo as segundas.

Como este estudo trata das relações entre língua e meio ambiente, é necessário encontrar o equivalente de MA na língua, bem como as relações que se dão entre ela e ele. Pelo que acabamos de ver que vige na ciência da ecologia, e pelo senso comum mencionado no início da presente seção, o ecossistema da língua só pode resultar das inter-relações que se dão entre a língua (L), o povo 
(P) que a usa e o território (T) em que esse povo vive e convive. Esse ecossistema constitui o que vem sendo chamado de ecossistema fundamental da língua (EFL). A expressão pode ser lida também como entorno, ou ecologia, fundamental da língua. Essas alternativas terminológicas em nada afetam a precisão científica. Quando falamos em EFL, sabemos que isso leva única e exclusivamente ao que está esquematizado na figura 1 , que, às vezes, é também chamado de comunidade.

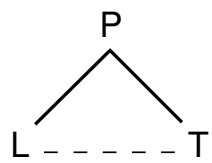

Comunidade

Figura 1

É importante ressaltar que esse modelo apresenta um paralelismo impressionante com o signo de Peirce. Para esse autor, "um signo, ou representame, é algo que, sob certo aspecto ou de algum modo, representa alguma coisa para alguém" (1972, p. 94). Para entender o que isso significa, partamos do que está exposto na figura 2, que mostra como Ogden \& Richards (1972, p. 32) representaram essa concepção de signo.

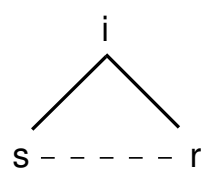

Figura 2

Na representação da figura 2, s está para "algo", que é o representame ou signo; $r$ está para "alguma coisa" que, no caso, é o referente; $i$ representa o "para alguém", ou seja, é o signo como interpretado por alguém, o interpretante de Peirce. Ainda nos termos desse autor, e como fora salientado por Ogden \& Richards (1972), não há relação direta entre $s$ e $r$, exatamente como não há relação direta e imediata entre $\mathrm{L}$ e $\mathrm{T}$, na figura 1 , o que está representado pela linha segmentada e será discutido detalhadamente mais abaixo.

Além do precedente histórico no signo de Peirce, o ecossistema fundamental da língua tem outros antecessores. Como mostra Trampe (1990, p. 190), o psicólogo canadense Albert Bandura (cf. BANDURA, 1969) fízera uso de três categorias 
que são equivalentes aos $\mathrm{P}, \mathrm{T}$ e L da figura 1. Ainda segundo o autor, Bandura estaria simplesmente alargando conceitos usados pelo psicólogo Kurt Lewin desde 1935, no caso, o famoso Lebensraummodell (modelo do espaço vital). Lewin chegou à fórmula $\mathrm{B}=\mathrm{f}(\mathrm{PE})$, em que $\mathrm{B}=$ behavior (comportamento), $\mathrm{P}$ $=$ person $\mathrm{e} \mathrm{E}=$ environment (meio ambiente). Lewin, por seu turno, recuaria a outras fontes, como J. Loeb (cf. LEWIN, 1935). É interessante acrescentar que Trampe (1990, p. 190) representa as relações estudadas por Lewin e Bandura como se vê na figura 3 .

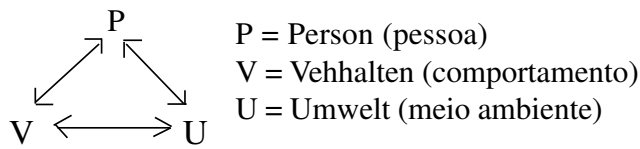

Figura 3

Empregando outras palavras, essa figura é a própria representação do EFL da figura 1. Com efeito, Verhalten (comportamento) equivale ao L da figura 1 e ao $s$ da figura 2, Person (pessoa) se equipara ao povo da figura 1 e ao $i$ da figura 2 assim como a Umwelt (meio ambiente) está para o T (território, meio ambiente físico) da figura 1 e o $r$ da figura 2.

Na própria linguística podemos encontrar precursores. Um exemplo seria a speech community (comunidade de fala) de Bloomfield (1933). Um pouco depois veio a reinterpretação sociolinguística que Gumperz fez dela (cf. GUMPERZ, 1972). Outros conceitos que anteveem o EFL são language community bem como a Interaktions gemeinschaft (comunidade de interação) e Kommunikationsgemeinschaft (literalmente "comunidade de comunicação") da linguística alemã. Mas, independentemente de precursores históricos, o conceito é intuitivo e, como tal, um tanto óbvio. A tal ponto que se poderia dizer que não merece a atenção dos linguistas. Àqueles, porém, que acham que o conceito de EFL é demasiadamente óbvio, simples, seria interessante lembrar o que disse Noam Chomsky. De acordo com ele, "é importante aprendermos a nos surpreender com coisas simples - p. ex., pelo fato de que os corpos caem para baixo, não para cima, e que caem a uma determinada velocidade; de que, se empurrados, movem-se em uma superfície em linha reta, não em círculos, e assim por diante". Essas ideias simples podem levar-nos "a descobertas surpreendentes, embora os fatos sejam inteiramente óbvios para nós" (CHOMSKY, 1988, p. 43). 
Para outras pessoas, esse modelo, como qualquer modelo, é uma idealização, como a mal compreendida idealização de Chomsky (1965, p. 3).É importante observar que, sem idealizações, é impossível estudar as comunidades concretas, complexas. A física é toda feita de idealizações. Por que os linguistas deveriam ter medo delas? No devido lugar, o conceito de EFL pode e deve ser usado. Afinal, modelos não são a realidade; eles são modelos e, como tais, são necessariamente abstrações. Chomsky acrescenta que idealização "é um termo enganador, uma vez que ele significa um movimento na direção da realidade. Quando você fala de idealização, ou abstração, trata-se de um esforço para achar a realidade" (CHOMSKY, 1997, p. 184). "A ciência começa quando você compreende que, para encontrar a realidade, você tem que se afastar dos fenômenos" (p. 185). Algo semelhante já fora dito por Marx, que parte de uma visão de mundo diametralmente oposta.

Sendo o EFL o ecossistema maior e imediato em que a língua se insere, toda língua tem que se enquadrar nele. No entanto, tem-se objetado que a língua dos ciganos (romani), o hebraico, o esperanto e as línguas de sinais (ou gestuais), entre algumas outras (não muitas), invalidariam essa tese, uma vez que o conjunto de falantes de nenhuma delas teria um T próprio. O romani, o hebraico e as línguas de sinais pelo menos são línguas naturais. O esperanto nem isso é, ou seja, é uma língua artificial. Portanto, é uma língua altamente atípica, nos termos já mencionados anteriormente. O romani, porém, já deve ter tido seu EFL original, como os estudos filológicos têm demonstrado, na parte central do norte da Î́ndia. O hebraico também tinha o seu, embora a diáspora o tenha desfeito. $\mathrm{Na}$ década de quarenta, ele foi recomposto, no que é hoje o estado de Israel, independentemente dos problemas que isso possa ter acarretado para os palestinos. Como se vê, a atipicidade decorre sempre de vicissitudes históricas que sobrevêm após a formação da língua e respectiva comunidade, vale dizer, após a formação do EFL.

As línguas de sinais, como a LIBRAS, aparentemente seriam mais difíceis de se enquadrarem no modelo do EFL. Entretanto, se observarmos a distinção que se tem feito entre comunidade de fala e comunidade de língua, já antevista nos conceitos ingleses de speech community e language community, bem como nos dois conceitos alemães recém-vistos, veremos que também elas são línguas prototípicas. Comunidade de língua corresponde ao senso comum, à concepção laica já mencionada, ou seja, ao domínio do que chamamos "língua". Assim, a 
comunidade de língua portuguesa compreende Portugal, Brasil, Angola, Moçambique, Cabo Verde, Guiné-Bissau, São Tomé e Príncipe e, mais recentemente, Timor Leste. A comunidade de língua islandesa se restringe à Islândia, assim como a comunidade de língua da maioria dos povos ameríndios se restringe ao domínio territorial de seus falantes. A comunidade de fala, por seu turno, já é mais difícil de ser qualificada. Ela pressupõe um povo, cujos membros interagem quotidianamente entre si, convivendo e interagindo em determinado território, e não apenas vivendo nele. Assim, o Brasil é uma comunidade de fala; Portugal, outra comunidade de fala; Angola, outra; um pequeno povoado do interior, idem. Como se vê, o primeiro pré-requisito para a existência de uma comunidade de fala é T; o segundo, os membros de P em interação nesse T. Assim sendo, qualquer comunidade de falantes convivendo em determinado lugar que o linguista delimite para efeito de estudos é uma comunidade de fala, exatamente como faz o ecólogo ao delimitar um ecossistema que vai investigar. Em Couto (2005), eu tratei do assunto detalhadamente.

Nenhum dos autores que falaram das relações entre L e MA qualificou o que entende por MA de L.É bem verdade que (HAUGEN, 1972, p. 325) afirmou que "o verdadeiro meio ambiente de uma língua é a sociedade que a usa como um de seus códigos", o que restringe seu MA a apenas um, vale dizer, o MA social. Na verdade, a língua participa de pelo menos quatro MAs, dependendo de como a encaramos. O primeiro, como já adiantado aqui, encontra-se no interior do ecossistema fundamental da língua, ou seja, é a população $(\mathrm{P})$ e o território (T), juntos, sendo que T inclui todos os aspectos físicos do MA, como veremos com Sapir. É o MA fundamental da língua. Ele é seu MA geral e mais abrangente, identificado intuitivamente até pelo leigo. Enfim, encontramos o EFL quando encaramos a língua macroscopicamente, a distância, usada por um povo que habita determinado território. Os demais ecossistemas, ou melhor, subecossistemas, emergem dele, são mais específicos.

Quando encaramos a realidade microscopicamente, notamos que o ecossistema maior da língua (EFL) pode ser decomposto em três meios ambientes menores, dependendo de como encaramos as relações de L com P e/ou com T. Das inter-relações da língua com a totalidade dos indivíduos do povo que a fala, bem como das interações de cada um deles com os demais, temos o ecossistema social da língua, no qual se encontra o MA social da língua, ou seja, a sociedade. Se o foco forem as relações de L com cada membro de $\mathrm{P}$ 
isoladamente, como individualidade ou como realidade psíquica, o que encontramos é o cérebro e a mente, onde Lé formada, armazenada e processada. Trata-se, portanto, do ecossistema mental da língua, com o MA mental da língua. Por fim, podemos encarar L em relação a T e P em conjunto, tomando-se de $\mathrm{P}$ apenas a parte física, corpórea de cada indivíduo. Isso constitui o ecossistema natural da língua, juntamente com o respectivo MA. Resumindo temos (o hífen está por "em relação a"):

a. MA social da língua $=\mathrm{L}-\mathrm{P}\left(\mathrm{P}=\mathrm{p}_{1}, \mathrm{p}_{2}, \ldots, \mathrm{p}_{\mathrm{n}}\right)$ : $\mathrm{L}$ em relação à totalidade dos membros de $\mathrm{P}$ como indivíduos que se inter-relacionam (sociedade);

b. MA mental da língua $=\mathrm{L}-\mathrm{p}_{\mathrm{x}}$ de $\mathrm{P}: \mathrm{L}$ em relação ao cérebro/mente de cada membro de P;

c. MA natural da língua = L-PT: Lem relação ao mundo físico, que inclui os membros de $\mathrm{P}$ como corpos físicos.

O MA social é o mais estudado, e é o que Haugen e Sapir enfatizaram. O MA mental foi mencionado por Haugen, mas apenas de passagem. Para Chomsky $(1986,1988)$ e Lamb (2000), ele é o MA central da língua. Quanto ao MA natural, Sapir (1969) e Fill (1993) o mencionam. O primeiro chega a relacionar o léxico a ele. Quem propôs um modelo que engloba os três são Døør \& Bang (1996, p. 23), usando outro nome e partindo de outra perspectiva. Eles falam em três "dimensões" da língua, que são a bio-lógica ou física (= MA natural), a ideo-lógica ou mental (MA mental) e a sócio-lógica (MA social). Vejamos cada um desses ecossistemas, bem como o MA da língua no interior de cada um.

\section{O Ecossistema Social da Língua}

Vou começar pelo MA social porque é ele que está associado à visão laica de língua. Aquela que considera que todo povo convive em um território e tem a própria língua, como discutido na seção anterior. Vimos que o MA social da língua resulta das inter-relações de L com a totalidade dos membros de P e das inter-relações de cada um deles com os demais. Esse MA é mais conhecido como sociedade. Ele parece ser o MA mediato da língua, sendo o MA mental o imediato, embora haja muita divergência entre os especialistas. Algumas tendências acham que o MA mental seria o locus imediato do sistema da língua 
(gramática), como é o caso da gramática gerativa. Outros consideram que pelo menos os atos de interação comunicativa, que se dão em um lugar físico específico, estão imediatamente no MA social e até no MA natural. De qualquer forma, é o MA social que sanciona o que se forma no MA mental. Fatos "linguísticos" mentais que só ficassem em determinado indivíduo não pertenceriam à língua, morreriam com ele, fato de que a gramática gerativa não consegue dar conta.

Como já observado, a esmagadora maioria dos estudos sobre as relações entre língua e meio ambiente relacionam-na com o MA social. Até parece que o MAde L se restringiria a ele, o que está longe de ser verdade. Vimos na seção anterior que, para Haugen, MA de Lé a sociedade. No entanto, de passagem ele ressalvou que parte do MA de Lé de natureza psicológica e física (HAUGEN, 1972, p. 325). Ele estava pensando em questões como mudança linguística, variação, contato de línguas, multilinguismo, padronização e qualquer problema que surge devido ao multilinguismo e ao multidialetalismo. A mesma senda é trilhada por Fill (1993) e Mühlhäusler (2003). Aliás, esses dois autores enfatizam questões que têm a ver diretamente com uma visão política da língua, como o ambientalismo. Vejamos, então, que tipos de estudos se enquadram na rubrica MA social da língua.

Todo estudo sobre Le MA parte, de uma forma ou de outra, dos princípios da ecologia. OEFL recém-visto, por exemplo, parte do conceito de ecossistema. Todavia, a maioria dos estudiosos da relação entre Le MA social parte do princípio da diversidade e do princípio das inter-relações, embora um não exclua o outro. O que acontece é que ora se coloca o foco em um deles, ficando o outro em posição secundária, ora o contrário. Mesmo quando enfatizamos o ecossistema, o que vige dentro dele são inter-relações, o que pressupõe diversidade. $\mathrm{Na}$ presente seção explorarei as tendências que põem ênfase na diversidade e as que a põem nas próprias inter-relações. Começo pela questão das inter-relações.

Da perspectiva das inter-relações, ou interações, tem se tratado de diversas questões. Uma delas são as ecologias linguísticas complexas. Em primeiro lugar, vem o bilinguismo e o multilinguismo, com todos os problemas que suscitam. No caso do bilinguismo/multilinguismo societário, que é o que interessa aqui, surgem questões como a determinação da língua padrão ou estatal, por oposição a línguas nacionais e dialetos. A maioria dos países do mundo é multilíngue, como é o caso da Índia. E ela é apenas um entre os inúmeros outros 
casos de multilinguismo societário ou territorial. Os invasores ingleses delimitaram como território indiano o que compreendia diversos povos e línguas diferentes. De acordo com o Censo de 1961, existem aí cerca de 200 línguas, pertencentes às famílias indo-europeia, dravídica e sino-tibetana. Alguns autores chegam a falar em 1.652 línguas (COULMAS, 1985, p. 210). O fatoé que atualmente a constituição do país reconhece quinze línguas oficiais. Após a independência da Inglaterra em 1947, a constituição declarou o hindi como língua nacional, cuja escrita é o devanagari, embora para alguns essa língua seja a mesma que os muçulmanos do noroeste e do Paquistão chamam urdu, que usa a escrita árabe. Como o hindi era (e ainda é) alvo de muita resistência por parte dos falantes de línguas dravídicas do sul (como telugu, tamil, kannada e mayalam), a constituição declarou também a língua do invasor (inglês) como língua nacional até 1965. Como a resistência ao hindi continuou, o inglês foi declarado oficial por tempo indeterminado.

Da interação entre as línguas temos também o que vem sendo estudado sob a rubrica "contato de línguas", cujos resultados podem ser bastante variados. O contato de línguas geralmente se dá pelo deslocamento de um povo para o território de outro povo. Normalmente, o povo mais fraco é forçado a tentar aprender a língua do mais forte, em situação altamente desfavorável. Com isso, o resultado mais comum é o mais fraco aprender a língua do mais forte, mantendo influências de sua L1 na nova língua aprendida. É o que aconteceu na Península Ibérica. Com a invasão românica, os povos locais aprenderam o romanço, mas mantiveram traços de suas línguas, consideradas de substrato. O romanço, já sob a forma de português, espanhol e catalão, não desapareceu diante da invasão dos germânicos (409 d. C.) e dos árabes (711 d.C.). As línguas desses dois povos deixaram apenas alguns itens vocabulares. Entre os vocábulos germânicos, temos guerra, elmo, trégua, roubar e bando, além de nomes próprios como Rodolfo, Teodorico e Hilda. Entre os termos árabes, temos álgebra, algema, alface, enxaqueca, xarope e cifra, bem como fulano e a preposição até. A maior parte das palavras começadas por al- (artigo árabe) vêm dessa língua.

O povo mais fraco pode também adotar grande parte do vocabulário da língua do mais forte, mantendo a gramática praticamente intacta. É o que aconteceu com o chamorro das Ilhas Marianas e com as línguas das Filipinas: todas elas adotaram palavras espanholas maciçamente, mas continuaram a ser chamorro, tagalog, ilocano, etc. Algo semelhante aconteceu com a chamada media lengua do Equador. Pode acontecer também de o mais fraco opor 
resistência à adoção de termos estrangeiros, mesmo que a gramática comece a ser erodida pela pressão da língua do povo mais forte. É o que aconteceu com a linguagem do Cafundó (Sorocaba, SP), dos ciganos calon e com o ma'a ou mbugu, da Tanzânia, entre muitos outros casos.

Frequentemente, a língua do povo mais forte é apropriada pelos mais fracos, sobretudo se falam muitas línguas mutuamente ininteligíveis, de forma pidginizada, o que pode levar à crioulização, como ocorreu com o francês no Haiti e na Ilha Maurício e com o português na Guiné-Bissau, entre outras situações. Há muitas hipóteses e teorias para explicar o processo de crioulização. Algumas delas dizem que o crioulo é um pidgin que se tornou língua materna (nativização), outras afirmam que ele é um pidgin ou algo semelhante que se tornou língua principal de uma comunidade (comunitarização). Alguns estudiosos acham que a crioulização só se explica por processos sócio-históricos, outros consideram que apenas pela gramática se poderia dizer se uma língua é crioula ou não (cf. COUTO, 1996).

O contato entre as línguas pode levar à obsolescência e, no limite, à morte de uma das línguas. Isso está acontecendo com o romani dos ciganos. A sua variedade brasileira chamada calon já está em adiantado estado de deterioração. Só em algumas poucas comunidades ainda se encontram pessoas, geralmente as mais velhas, que ainda se lembram de algumas palavras da língua ancestral (MELO, 2005). Os hebreus, por seu turno, chegaram a perder por completo o hebraico, tendo desenvolvido uma variedade pidginizada de alemão (iídiche) na Europa do Leste e uma variedade reestruturada do espanhol na Península Ibérica (judeo-espanhol). Só mais tarde se fundou o estado de Israel, com o que o hebraico das Escrituras foi ensinado e reintroduzido como língua de um povo. Grande parte das línguas indígenas brasileiras já desapareceu por completo; outras estão em processo de atrição e obsolescência, o que pode levar a seu desaparecimento.

Os resultados do contato de línguas vistos até aqui se enquadram no que se tem chamado de ecologia das línguas. O mesmo princípio poderia ser estendido ao interior de cada língua, em que temos a questão da dialetação, como os dialetos sociais, os geográficos e as linguagens especiais ou jargões e as gírias.

Temos ainda a ecologia da interação comunicativa. Na verdade, tudo na língua tem a ver com ela. Para Saussure (1973, p. 27), por exemplo, "historicamente, o ato de fala vem sempre antes", ou seja, para ele a língua começa por tentativas 
de interação comunicativa. Em contrapartida, continua ele, "a língua é necessária para que a fala seja inteligível e produza todos os seus efeitos; mas esta é necessária para que a língua se estabeleça”. Existe ainda a ecologia da evolução linguística, fato que se deve a atos de interação comunicativa (interdialetal, interidioletal), ou tentativas de interação comunicativa (interlinguística), como mostrou muito bem Mufwene (2001). Quer dizer, a evolução linguística tem sempre a ver com o contato, que é um tipo muito especial de interação. Passemos, porém, às questões linguísticas que têm a ver com a diversidade.

Como já notado, é o conceito ecológico de diversidade que tem dado lugar à esmagadora maioria dos estudos que se enquadram nas relações L-MA. Sobretudo na Rio-92, emergiu o conceito de biodiversidade que, mais tarde, foi estendido à diversidade linguística (linguodiversidade), num sentido diametralmente oposto ao do rolo compressor padronizador da globalização. Na mesma linha de pensamento, defende-se o direito à diferença em geral, como se vê na expressão francesa vive la différence!

Fill (1993) combate a ideia de que o importante é ser grande (grandismo) e crescer (crescimentismo), que levam ao culto do desenvolvimento, a qualquer custo (desenvolvimentismo). Tem se mostrado que esse desenvolvimento tem beneficiado uma pequena minoria, tendo como consequência o empobrecimento de grandes contingentes da população, a favelização no Terceiro Mundo e a degradação do meio ambiente. Além disso, como nesse conceito de desenvolvimento o importante é consumir muita mercadoria, muitos indivíduos têm feito qualquer coisa para conseguir ter acesso às bugigangas que o mercado nos impinge. Cada indivíduo quer conseguir o que acha que é bom para si, custe o que custar. Aí valem roubos, assassinatos, assaltos, desvios, drogas, corrupção. Trata-se de um individualismo exacerbado, que tem levado também a uma degradação das relações entre as pessoas. Não existe mais o próximo, mas apenas o estranho.

Na mesma linha de pensamento, os estudiosos têm combatido quase todo tipo de -ismo. Começa-se pelo antropocentrismo, que considera os humanos como os reis da criação, como já dizia Protágoras. Tudo mais existe para que eles usem e abusem. Por isso, acham-se no direito de matar seres vivos por prazer (caça). Matam até seres da própria espécie com requintes de crueldade. Seres de nenhuma outra espécie fazem isso, o que tira dos humanos qualquer direito à veleidade de se considerarem mais importantes do que os demais. Apesar disso, usam conceitos relacionados com outros animais pejorativamente. É o caso 
de termos como animalesco, bestial, selvagem, simiesco, burro e porco. Isso é uma grande ofensa aos referidos animais, uma vez que entre eles não há psicopatas que torturam as vítimas, estupram e matam, com requintes de crueldade.

Em seguida vem o etnocentrismo, segundo o qual o bom e correto é o que existe em minha cultura; o que há de diferente nas demais culturas está errado. Os próprios gregos já diziam que todos os demais povos eram bárbaros, pois não eram "civilizados" como eles. Afirmar que Europa, Estados Unidos e Japão são desenvolvidos e que África é subdesenvolvida também se insere nesse contexto. Essa ideologia tem levado a uma intolerância entre povos que frequentemente tem dado lugar a guerras e outros conflitos. Enfim, há muitos conceitos e atitudes que revelam etnocentrismo.

Fala-se em classismo ou aulicismo, que consiste em considerar que o que é da cidade, urbano, é bom, requintado, tem "urbanidade", "civilidade" (de civis "cidade'), ao passo que o que é da zona rural é "rude", "rústico", palavras que têm a mesma raiz que "rural". Antigamente, os habitantes da corte eram "corteses", enquanto os habitantes da vila eram "vilões". No Brasil, termos como "caipira", "capiau", "jeca" são todos pejorativos, e associados a "atraso", estão distantes do "desenvolvimento". No entanto, é na cidade que existe a hipocrisia de se usarem eufemismos para se referir a determinadas partes do corpo ou atos fisiológicos. Assim, o pudor hipócrita dos urbanitas fez surgirem expressões para substituir eufemisticamente "bunda" (bumbum), "cu" (ânus), "cagar" (fazer cocô), "mijar" (fazer xixi) e assim por diante, como se, ao evitar a palavra, estivessem suprimindo algo desagradável, como o referente ausente de Adams (1991).

$O$ androcentrismo também se manifesta linguisticamente. Em uma sala de aula de 50 estudantes, se apenas um for do sexo masculino, dir-se-á "os alunos". Tudo que se refere ao órgão sexual masculino é usado de modo "engrandecedor", tanto que muito homem vive pegando nele, mesmo em público, a fim de checar sua "masculinidade", se ele ainda está no lugar. Termos como caralho e cacete, são usados em expressões como "grande pra caralho/cacete" como aumentativos. Mais recentemente, os jovens introduziram a expressão "carai, véi!" O órgão da mulher, por seu turno, é frequentemente mencionado de modo pejorativo, como se pode ver nos termos "perereca" e "perseguida", embora haja também "florzinha". Sob a forma de machismo, o homem "come" a mulher, que "dá" para ele ou, então, ele "mete" nela. O ato sexual é algo que 
ele faz nela, não algo que os dois fazem para o prazer de ambos.

A diversidade linguística é considerada necessária ao bem-estar dos povos. As minorias linguísticas, os falantes de dialetos menores e/ou mais distantes da "civilização" urbana têm tanto direito à existência quanto as grandes línguas mundiais, como o inglês. Tanto que já se propôs a Declaração Universal dos Direitos Linguísticos. Assim como o desaparecimento de uma espécie viva pode ocasionar um distúrbio irreparável na cadeia alimentar dentro do ecossistema, o desaparecimento de uma língua significa a perda de todo um conhecimento nela depositado, uma maneira de ver o mundo, uma tecnologia ambientalmente correta. A morte de uma língua leva a um empobrecimento da cultura mundial.

Tem-se criticado o discurso de grandes empresas multinacionais, cuja ação é nociva ao meio ambiente, mas querem passar-se por defensoras dele. Por exemplo, quando uma empresa de petróleo anuncia que baixou os preços como algo bom, está omitindo que isso levará ao aumento do uso de veículos. A consequência será mais dióxido de carbono no ar, que contribuirá para aumentar o buraco na camada de ozônio que protege a vida na Terra dos raios ultravioleta, contra o efeito estufa e assim por diante. Uma firma produtora de agrotóxicos se vangloria de que seus produtos levam a um aumento na produção de soja, por exemplo, omitindo o fato de que seu produto mata os micro-organismos do meio ambiente, o que causa uma reação letal em cadeia, além de a soja ser produzida não para alimentar o povo, mas para exportar para Japão e China, a fim de dar lucros ao grande produtor que, frequentemente, deposita o dinheiro nas Ilhas Cayman ou na Suíça.

Enfim, esses são alguns dos tópicos que se têm estudado, entre diversos outros que se abrigam sob a rubrica "MA social da língua". O que fiz aqui foi apenas dar uma ideia do que se tem feito. Para maiores detalhes, pode-se consultar Fill (1993).

\section{Ocossistema Mental da Língua}

Apesar do nome "meio ambiente mental da língua", a mente é apenas um dos constituintes do ecossistema mental da língua. Na verdade, esse MA compreende o sistema nervoso central e o periférico. O primeiro é composto pelo encéfalo e a medula espinhal ou raquidiana. $O$ encéfalo é formado pelo cérebro, o cerebelo, o tálamo, o hipotálamo e o tronco encefálico. O cérebro, para o que 
aqui interessa, subdivide-se em hemisfério direito e hemisfério esquerdo. $\mathrm{O}$ sistema nervoso periférico, constituído pelos nervos e gânglios nervosos, também se interliga ao cérebro ou ao encéfalo em geral, pois é ele que estabelece comunicação do indivíduo com o MA natural. Assim sendo, talvez o melhor termo para esse MA da língua fosse "MA cerebral", "MA encefálico" ou "MA nervoso". No entanto, temos também a mente. Embora lexicólogos, psicólogos e filósofos não tenham chegado a um acordo sobre como defini-la, emprego-a no sentido de "funções cerebrais", que emergem da neurologia do cérebro, sem entrar nos detalhes de sua conceituação. Achei mais adequado manter a denominação "MA mental”, mesmo porque na gramática gerativa se enfatiza muito a mente. Esse MA intermedeia o MA natural e o MA social da língua, no sentido de que, da perspectiva do cérebro, ele faz parte do MA natural e, da perspectiva da mente, de certa forma se direciona para o MA social.

Ironicamente, o MA mental da língua é um dos mais difíceis de se estudar, a despeito de estar delimitado pela caixa craniana. A dificuldade está no fato de seu estudo requerer aparelhagem sofisticada. De qualquer forma, tudo que acontece nele tem que ser sancionado pelo MA social, com o apoio do MA natural. É no MA mental que a língua é formada, armazenada, processada e transformada. Ele é o locus imediato da língua. Ele vem sendo estudado parcelarmente por ciências como a neurolinguística e outras neurociências, pela psicolinguística, pela biolinguística e pelo conexionismo, entre outras. A neurolinguística, por exemplo, investiga processos de aquisição (formação), processamento e desestruturação da linguagem. O sistema nervoso, que inclui o cérebro, está inter-relacionado diretamente com o MA natural, aliás, faz parte dele, e, indiretamente, com o MA social. Em síntese, pela mente, o MA mental se relaciona com a sociedade; pelo cérebro, com o mundo natural.

Infelizmente, ainda sabemos muito pouco sobre o modo como a língua é formada, armazenada, processada e transformada no cérebro. Até hoje ainda não se chegou a uma compreensão plena de quais são os mecanismos cerebrais que estão envolvidos, por exemplo, no uso dos sons, do léxico, da morfologia, da sintaxe e outros aspectos da língua. No entanto, alguma coisa valiosa já sabemos sobre as relações que se dão entre língua e cérebro/mente, vale dizer, sobre o MA mental da língua. Uma delas diz respeito à localização dos processos linguísticos, a lateralização, descoberta por Pierre Broca (1824-1880). Ele foi o primeiro investigador a constatar a dominância do hemisfério esquerdo na articulação da 
língua. Por "dominância" deve-se entender que os processos linguísticos se dão preferencial e majoritariamente nesse hemisfério, o que não significa que o hemisfério esquerdo também não seja ativado de alguma forma. Talvez pelo fato de que, como constatara ainda Broca, produzir e entender linguagem envolvem tarefas cognitivas diferentes.

Uma outra constatação também antiga sobre as relações da linguagem com o cérebro foi feita por Carl Wernicke (1848-1905). Ele concluiu que as imagens sonoras estavam localizadas no lóbulo temporal esquerdo, posterior ao córtex auditivo primário.

As pesquisas de Broca foram feitas com pacientes afásicos. Nos anos sessenta, encetaram-se estudos do comportamento linguístico de adultos normais. Esses estudos confirmaram em grande parte as constatações dele. Encontraramse novas evidências a favor da especialização sinistrolateral. O processamento de sinais da fala se dá prioritariamente no hemisfério esquerdo, ao passo que o processamento dos demais sinais se dá prioritariamente no hemisfério direito. De qualquer forma, há situações em que as coisas se complicam. É o caso dos bilíngues. Os adultos que aprenderam duas línguas no começo de suas vidas ativam regiões do cérebro que se interseccionam, quando processam as duas línguas. Aqueles que aprenderam a segunda língua mais tarde ativam duas regiões distintas do cérebro para as duas, uma região para cada língua (cf. PARADIS, 1980).

Investigações individuais têm levado a conhecimentos parcelares. Como diz Levelt (2000, p. 844), "as áreas do lóbulo temporal esquerdo adjacentes ao córtex auditivo primário se tornaram mais especializadas para o armazenamento dos códigos fonológicos. Várias áreas perisylvianas do hemisfério esquerdo (temporal, parietal, insular, frontal) estão ligadas às complexidades do processamento linguístico, indo da análise e síntese sintática, morfológica, fonológica até a fonética".

Quando se fala em lateralização, em localização da linguagem no cérebro, é preciso entender a afirmação cum grano salis. Com efeito, "os novos estudos sugerem, por exemplo, que não há uma 'área linguística' unificada no cérebro na qual os sinais linguísticos são processados. Sistemas cerebrais diferentes se associam a aspectos diferentes do processamento da linguagem. As áreas de processamento linguístico do cérebro incluem muito mais regiões do que as áreas clássicas de Broca e Wernicke" (KUHL, 2000, p. 111).

Não se tem certeza se essa tendência à sinistrolateralização já está presente no estágio inicial de aquisição da língua. O que se sabe com relativa 
segurança é que essa especialização para a linguagem se desenvolve com a maturação, em vez de ser transmitida in totum geneticamente. A experiência linguística resultante do contato com o MA produz um mapeamento que altera a percepção. Além disso, a aprendizagem linguística altera o processamento cerebral do sinal, o que leva a mapas mentais complexos. Até informações provenientes de outros sentidos que o da audição podem influir na percepção e no processamento da fala. A informação visual, por exemplo, exerce um importante papel nesse processo, como já se sabia na linguística há muito tempo. De modo mais geral, o reconhecimento e a nomeação de diferentes tipos de objetos, tais como animais e instrumentos, estão associados a diferentes redes de regiões corticais.

Os itens lexicais não estão armazenados em um único ponto. Como o cérebro é uma complexa rede de conexões entre neurônios, os conceitos associados a cada um desses itens é apenas um ponto (nó) em que uma série dessas conexões se sobrepõem. Como diz Lamb (2000, p. 177), “o nó para uma categoria conceptual parece ter conexões para/de um grande número de nós que representam suas propriedades, para/de outros nós conceptuais e para/de outros subsistemas. Por exemplo, conceitos para categorias de objetos visíveis têm conexões com nós da área visual; os de categorias de objetos auditivos, para/de nós da área auditiva e assim por diante. Tomando o conceito ${ }^{C}$ gato, por exemplo, temos conexões visuais relativas à aparência dos gatos, conexões auditivas para 'miau' e outros sons feitos pelo gato, conexões táteis para o que sentimos ao tocá-lo. Além disso, há conexões para outros conceitos que representam informação sobre gatos no sistema de informação da pessoa em cujo sistema essas conexões se formaram". Assim sendo, "o conhecimento de uma pessoa sobre gatos é representado no sistema de informação por uma pequena rede, que compreende centenas ou milhares de nós, incluindo uma rede visual para traços visuais, uma rede auditiva para o 'miau' e assim por diante, todas 'mantidas juntas' por um nó coordenador central, ao qual podemos dar o rótulo " gato"”. A linguística neurocognitiva desse autor desenvolveu um sistema gráfico para representar essas conexões, de modo quase icônico.

No que concerne à sintaxe, sabemos que não é possível delimitar uma área única do cérebro dedicada a ela, seu processamento se baseia em uma ação concertada de diversas áreas, cada uma com sua especialização. Entretanto, sabemos também que ela tende a se concentrar nas áreas frontais esquerdas (BROWN, HAGOORT \& KUTAS, 2000, p. 891-892). 
Para se entender uma frase escrita ou falada é necessário que haja a confluência de diversos tipos de conhecimento, linguístico e não linguístico, cada um contribuindo com sua parte. Cabe ao investigador construir uma representação integrada. A hipótese da modularidade tem a ver diretamente com isso.

Se, por um lado, os dados resultantes da observação das lesões sugerem que é impossível delimitar uma área do cérebro inteiramente associada ao processamento sintático, por outro lado, sabe-se que o córtex temporal anterior não tem sido associado a nenhuma função linguística. No entanto, as pesquisas têm demonstrado que ele estaria associado a déficits sintáticos. Conjuntos de áreas do córtex esquerdo perisylviano contribuem com o processamento sintático e alguns processos semânticos. Enfim, os dados indicam que o processamento sintático se baseia na ação conjunta de diferentes áreas do cérebro, cada uma com sua especialização relativa. É importante ressaltar também que as áreas envolvidas na compreensão da fala não são necessariamente as mesmas que se associam a sua produção.

Nos últimos anos, os estudos neurolinguísticos têm experimentado um notável avanço. Isso foi facultado pela introdução de técnicas não invasivas, mediante as quais se pode ver que partes do cérebro são ativadas durante a fala. Essas técnicas são basicamente de dois tipos: as hemodinâmicas e as eletromagnéticas. As hemodinâmicas são PET (positron emission tomography) e fMRI (functional magnetic resonance imaging), ambas de ótima resolução espacial, mas de fraca resolução temporal. As técnicas eletromagnéticas são EEG (electroencephalography) e MEG (magnetoencephalograpy), de excelente resolução temporal, embora não tenham boa resolução espacial. Infelizmente, porém, ainda sabemos muito pouco sobre como os sinais eletrofisiológicos e os hemodinâmicos se relacionam.

Quando ouvimos ou lemos uma palavra, nosso cérebro ativa não só a ela mas também outras que podem ser associadas a ela. Isso mostra que nosso conhecimento da língua inclui não apenas as palavras reais (ativadas), mas também as potenciais (inativadas), do mesmo modo que entendemos não apenas as frases que já ouvimos, mas todas as frases possíveis da língua, inclusive as sem sentido, como a de (3), a seguir. Isso contribui para a autonomia relativa da linguagem vis-à-vis MA, que será detalhada na seção 6.

Além das neurociências e da psicolinguística, as pesquisas no âmbito do conexionismo também podem ser de grande valia para se entender o MA mental 
da língua, uma vez que ele parte do pressuposto de que o cérebro consiste de redes altamente interconectadas de neurônios. Os pesquisadores constroem modelos altamente idealizados dessas redes no computador a fim de explorar suas possibilidades computacionais e representacionais. Como diz Sharkey (1996, p. 155), "conexionismo ou computação neural é um paradigma de processamento de informação que representa uma tentativa de imitar a arquitetura e os processos computacionais do cérebro". Um fato interessante é que as redes conexionistas têm a capacidade de "aprender" pela exposição a dados, algo como deduzir uma "gramática" com base em dados (ver também FRANÇOZO, 2005). Steven Pinker (2000) tem sérias restrições a esse modelo.

O que comentei aqui sobre o MA mental de Lé apenas uma pequena amostra. Existem ainda inúmeras outras inter-relações em seu interior. Muitos outros fatos ficam de fora da discussão. Por exemplo, o número de palavras que cada indivíduo domina giraria em torno de 50.000 (FRANÇA, 2005), embora esse número seja difícil de ser determinado, por motivos que ficarão mais claros na discussão sobre léxico e morfologia na seção 6. Entre as questões em aberto, teríamos a determinação do locus da gramática. Para Chomsky, ela se localiza no MA mental; para Saussure, no MA social. É provável que nenhum dos dois esteja certo, e que ela esteja em ambos.

\section{O Ecossistema Natural da Língua}

Vimos que, embora as relações entre Le MA natural tenham sido das primeiras a fazer parte das reflexões dos filósofos antigos, na linguística elas dificilmente têm tido guarida. Isso é estranho, uma vez que toda língua é falada por um povo, que consta de indivíduos de carne e osso que têm que viver e conviver em um território definido. O que é mais, a própria matéria que compõe seus corpos físicos provém da natureza, e a língua é uma espécie parasita deles, no sentido biológico, não no sentido social (MUFWENE, 2001). Diante disso, como é que língua poderia não ter nada a ver com o mundo físico, natural? $\mathrm{Na}$ presente seção, vou explorar esse tipo de relação, deixando suas consequências linguísticas para a seção seguinte.

Além das reflexões filosóficas iniciadas com os gregos, em outras ciências que não a linguística têm aparecido diversas manifestações sobre a relação entre língua (ou cultura em geral) e MA. Entre os convencionalistas, poderíamos citar 
a corrente de pensamento que vai de Hamann (1730-1788), Herder (1744-1803), passando pela semântica geral de Korzybski (1879-1950), até Humboldt(1767-1835) e Weisgerber (1950). Essa corrente de pensamento encara a língua como se ela estivesse entre nós e o mundo, como se pode ver na figura 4, tomando-se T não apenas por "território" mas por todo o mundo físico.

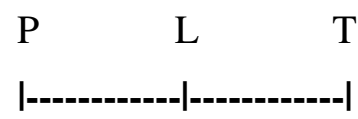

Figura 4

Trata-se, como se vê, de uma respeitável tradição. O problema é que essa concepção parte do pressuposto de que "o mundo é construído pela língua", como diz Schaff (1974). Para Weisgerber (1950), por exemplo, a visão de mundo (Weltbild), de que a língua faz parte, fica entre nós $(\mathrm{P})$ e o mundo $(\mathrm{T})$, o que ele chamou de entremundo (Zwischenwelt). A consequência disso é que não teríamos acesso direto ao mundo, mas só via linguagem. O mundo é aquilo que nossa linguagem nos mostra. Como afirmou Schaff (1974), isso representa uma visão metafísica de nossa relação com o mundo, uma vez que, assim, "a língua [...] é promovida ao papel do criador, do demiurgo do único mundo acessível ao homem" (p. 41), enfim, “o sistema definido de uma língua 'cria' uma imagem do mundo (fora da qual, nada pode, entretanto, ser dado no conhecimento)" (p.42). Ele a chama de "mística e idealista", o que significa que não deve ser seguida em um estudo científico da linguagem. No entanto, Schaff ressalva que há um fundo positivo nessa hipótese. Esse fundo é o fato de ela reconhecer que "as diferenças linguísticas equivalem a diferenças na classificação dos objectos do mundo exterior, - o que se projecta em definitivo sobre nossa visão do mundo" (p. 46) (ver autonomia relativa de L, adiante).

A visão do entremundo (Zwischenwelt, Weltbild) foi criticada por diversos outros pensadores, não apenas por linguistas. Veja-se, por exemplo, o proponente da filosofia da ecologia profunda, Arne Naess. Contrapondo-se ao que Michael Zimmermann dissera dele, comparando-o a Heidegger, Naess (1997) afirma: “A minha ontologia gestáltica é uma espécie de realismo ontológico, no sentido de que temos acesso direto aos conteúdos da realidade em nossas experiências espontâneas". Logo abaixo, ele diz que "nas experiências espontâneas, temos acesso direto ao que é real. Nós experienciamos algumas coisas como sólidas, 
relativamente isoláveis e intimamente relacionadas umas com as outras", embora nada "esteja absolutamente isolado". Ele gosta de falar sobre coisas ou itens de preferência a 'fenômenos' (realismo ontológico?). Rechaça a ideia de Derrida de que "nunca temos acesso direto à natureza em si ou como um todo, e que ela seria, ao contrário, um fenômeno social, cujo significado é sempre contestado em discursos particulares, locais".

No mesmo sentido, temos, nos Estados Unidos, a tradição que começa com Boas, passa por Sapir e chega a Whorf, culminando na conhecida Hipótese Sapir-Whorf (cf. SCHAFF, 1974, p. 89-141). A versão radical dessa hipótese afirma que nossa visão de mundo é determinada por nossa língua, exatamente como o que acaba de ser comentado nos parágrafos precedentes. Há, porém, uma versão mais moderada da hipótese, que afirma que nossa visão de mundo é influenciada e, até certo ponto, direcionada, por nossa língua. Há experiências psicolinguísticas que comprovam essa segunda versão. Por exemplo, se perguntarmos a um falante das línguas tupi e guarani qual é a tradução de "verde", ele dirá que é obï. Se perguntarmos qual é a tradução de "azul", ele dirá do mesmo modo que é obï. Isso significa que, espontânea e inconscientemente, ele chama a cor do céu e a de uma folha de árvore de $o b \ddot{i}$. No entanto, se lhe questionarmos e perguntarmos se efetivamente a cor do céu e a da folha são exatamente iguais, ele dirá que, bem, não são a mesma coisa. Quer dizer, se agir sem refletir, dirá que são a mesma coisa, mas, se refletir um pouco, dirá que são diferentes. Não havendo nada em contrário, ele agirá como sua cultura e sua língua o prepararam para agir, fornecendo-lhe apenas uma palavra para o que chamamos de verde e o que chamamos de azul.

Do lado naturalista, ou seja, daqueles que não aceitam a ideia de que a língua se interpõe entre nós e o mundo, também há uma longa tradição, quase sempre fora da linguística. Poderíamos citar Montesquieu (1689-1755), com sua teoria de que o clima influencia a cultura e, consequentemente, a língua. $O$ economista fisiocrata Quesnay (1694-1774) equiparava o processo econômico ao sistema sanguíneo. Poderíamos incluir o geógrafo Friedrich Ratzel (1844-1904), todo o materialismo dialético de Marx e Engels, bem como o linguista soviético Marr e o filósofo Adam Schaff. Na Antiguidade, temos os já mencionados Heráclito e Crátilo. É bem verdade que há exageros em muitas dessas hipóteses. No entanto, "entre o idealismo de Hume que não admite que a liberdade humana possa ser condicionada por fatos de ordem física e o determinismo natural de 
Montesquieu, de Condorcet e de Comte, que faz do homem um joguete das forças naturais, devemos constatar que a vida humana, sobretudo a econômica, depende em larga medida das condições climáticas, geográficas, geológicas e biológicas em que se encontra" (TONNEAU, 1934, p. 116). Essa segunda visão está representada na figura 5, seguindo a representação do linguista alemão Gerhard Helbig (cf. HELBIG, 1975, p. 118).

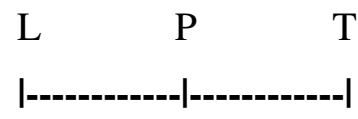

Figura 5

De acordo com essa visão, somos nós que nos interpomos entre o mundo e a linguagem. Isso implica que temos acesso direto ao mundo, independentemente de L, mas, significa também que nós (P) vivemos e convivemos no mundo (T). Formamos L com material tirado do mundo, mesmo porque nós próprios vivemos nele e somos parte dele. Como disse Mufwene (2001), Lé parasita de P, no sentido ecológico. De acordo com essa perspectiva, o mundo dá lugar à população, que dá lugar à linguagem, nessa direção.

Edward Sapir, tantas vezes já mencionado, foi um dos primeiros linguistas a relacionar língua e meio ambiente, inclusive MA físico, que para ele compreende "os aspectos geográficos, ou seja, a topografia (costa, vale, planície, chapada ou montanha), clima e regime de chuvas bem como o que se pode chamar a base econômica da vida humana, ..., a fauna, a flora, e os recursos minerais do solo". Acrescenta que "o ambiente físico só se reflete na língua na medida em que atuaram sobre ele as forças sociais" (SAPIR, 1969, p. 44-45), ou seja, via P.

Sapir salienta que a língua pode, em princípio, sofrer influências do ambiente "quanto a seu assunto ou conteúdo, isto é, o léxico; talvez não quanto ao sistema fonético" nem "quanto à forma gramatical", que compreenderia a morfologia e a sintaxe. No que concerne ao primeiro tipo de influência, afirma que "o léxico da língua é que mais nitidamente reflete o ambiente físico e social dos falantes". Tanto que, "se houvesse à nossa disposição um tesouro assim cabal da língua de uma tribo, poderíamos daí inferir, em grande parte, o caráter do ambiente físico e as características culturais do povo considerado". Cita o caso da tribo costeira nutka, com seu rico vocabulário marinho; dos paiútes dos planaltos desertos, com minuciosas designações topográficas. Contudo, sempre 
ressalta que a mera presença de um fenômeno no ambiente não faz surgir um termo para designá-lo. Isso só acontece se os membros da comunidade têm algum interesse nele (SAPIR, 1969, p. 45-47).

A despeito do que acabamos de ver com Sapir, o linguista moderno John Haiman defende uma certa iconicidade entre gramática e MA. Às vezes se tem certa motivação na ordem da narrativa, como na famosa frase de César Veni, vidi, vici (vim, vi, venci). Geralmente, "a ordem das declarações em uma narrativa correspondem à ordem dos eventos que descrevem" (1980, p. 516). Um outro caso é o isomorfismo (tendência a uma relação biunívoca entre designans e designatum), que seria universal. Após comprovar suas teses com exemplos tirados de diversas línguas, Haiman diz que "desde a revolução transformacional, tem se afirmado que a estrutura da língua reflete a estrutura do PENSAMENTO, e que o seu estudo [da língua] provê 'uma janela para a mente'. Ao argumentar, como tenho feito, em prol da iconicidade da gramática em geral, eu defendo a tese de que a estrutura do pensamento, por seu turno, reflete a estrutura da REALIDADE mais do que o modismo atual o admite. Por fim, eu acho que sobre muitos (se não todos) os universais formais da sintaxe que atualmente atraem a atenção da maioria dos sintaticistas teóricos, descobrir-seá que refletem propriedades do mundo, e não propriedades da mente em si. Descobrir-se-á que 'em parte mediante o estudo da sintaxe, poderemos chegar a um razoável conhecimento da estrutura do mundo"' [citando Bertrand Russel] (HAIMAN, 1980, p. 537).

Para reforçar a tese de Haiman de que não apenas o léxico de L reflete MA, seria interessante lembrar que na sintaxe o que predomina são relações, como as de inclusão (oração relativa dentro da principal), adjacência (coordenação), superioridade/inferioridade (a principal em relação à subordinada), inferioridade, antes/depois (como na anáfora), etc. Pois bem, todos esses conceitos foram introjetados pela mente humana pelo fato de existirem no mundo. A relação de inclusão, por exemplo, pode ter a ver filogenética e ontogeneticamente, por exemplo, com um caroço dentro da fruta, que independe de um observador. A relação de superioridade/inferioridade pode decorrer da observação de uma pedra sobre outra, entre outras possibilidades. É por isso que a maioria das línguas, se não todas, codificam as principais relações em preposições. Das relações espaciais decorreriam as temporais; de ambas, as relações puras. Como disseram Ogden \& Richards (1972, p. 52), Heráclito achava que "a estrutura da 
fala humana reflete a própria estrutura do universo". Enfim, a gramática tem muito a ver com a ecologia das relações espaciais.

\section{Autonomia relativa da língua diante do mundo}

Há uma intrincada teia de inter-relações entre os três MAs da língua. O MA mental se inter-relaciona com o MA social na medida em que este sanciona o que se dá naquele. É o MA social que garante a continuidade dos fatos que surgem no MA mental. Só surge algo no MA mental devido ao contato da mente individual em questão com outra mente (p. ex., nos atos de interação comunicativa), frequentemente em decorrência de relação com o MA natural. O MA mental, por seu turno, se relaciona com o MA natural porque este lhe dá a infraestrutura física, que é o cérebro. O MA natural se relaciona não só com o MA mental mas também com o MA social. É no MA natural que membros de P se juntam e interagem. É a convivência deles aí que leva à formação, uso e transformação da língua. A copresença no espaço leva à interação, que começa pela comunhão, mas pode evoluir para algum tipo de comunicação verbal.

Aqui eu vou retomar as relações entre L e MA, da perspectiva de suas manifestações na língua. Veremos que, após formada, L adquire uma relativa autonomia diante da MA, autonomia que tem sido absolutizada pela corrente exemplificada na figura 4 . Veremos que se trata literalmente de autonomia relativa, para a qual contribuem todos os níveis, setores ou subestruturas da língua. Vale dizer, o léxico, a sintaxe, a morfologia e a fonologia.

Sabemos que o léxico é a parte da língua que mais diretamente se relaciona com o mundo, como acabamos de ver com Sapir. Praticamente toda língua tem uma palavra para "árvore". Entretanto, essa palavra surgiu não para os membros da comunidade "colocar" árvores no mundo, de acordo com a visão de que só temos acesso ao mundo via língua, que o mundo seria socialmente construído. Pelo contrário, a palavra "árvore" existe na língua porque existem árvores concretas no mundo. Se elas não existissem, não teria surgido a palavra. Alíngua está inextricavelmente ligada ao mundo, existindo em função dele. No entanto, após formada, ela pode adquirir (e adquire) uma autonomia relativa diante dele. No caso específico dos lexemas monomorfêmicos, após formados, podem ser usados metafórica ou metonimicamente. Por exemplo, a palavra "árvore" pode ser usada como metáfora para designar a representação gráfica de uma oração 
complexa, da árvore genealógica darwiniana, além da representação arbórea da gramática gerativa, entre outras. A palavra "cabeça" pode ser usada metonimicamente para indicar a parte superior de algo, inteligência e assim por diante. Além disso, temos as polissemias, as homonímias, as sinonímias e outros fenômenos que alargam o uso de palavras que surgiram como projeção de aspectos do meio ambiente. Veremos um pouco mais adiante que na morfologia e na fonologia a autonomia relativa do léxico se alarga ainda mais. Tudo isso mostra que os recursos de $\mathrm{L}$ podem ser reciclados.

Talvez seja na sintaxe que essa autonomia relativa se manifeste mais amplamente, pelo menos de modo mais perceptível. Vejamos as frases de (1). (1)

(a) Menino dorme

(b) O menino dorme

(c) O menino pequeno dorme

(d) O menino pequeno doente dorme

(e) O menino pequeno doente dorme tranquilamente

Numa situação filogenética e ontogeneticamente original, a primeira frase a emergir deve ter sido (1a), como provam os estudos de aquisição de língua pela criança, bem como alguns pidgins e crioulos. A forma (1b) já acrescenta a informação de que o menino em questão é conhecido, expressa no artigo definido. Em (1c), temos mais informação, ou seja, a restrição de que o menino em questão é pequeno. Em (1d) vê-se a informação adicional de que o menino pequeno em questão está doente. Por fim, (1e) acrescenta a circunstância de que o sono do menino é tranquilo.

A sentença (1e) é perfeitamente paralela à de (2).

(2) Fonemas oclusivos surdos ocorrem frequentemente

A sentença de (2) pode ocorrer normalmente em uma aula de linguística, sobretudo de fonologia. O que interessa, porém, é que ela é paralela às de (1e) e de (3a), que é tradução literal da de (3b).

(a) Ideias verdes incolores dormem furiosamente

(b) Colorless green ideas sleep furiously 
A sentença (3b) foi fabricada pela primeira vez por Chomsky, com a finalidade de mostrar que "qualquer procura por uma definição de 'gramaticalidade' baseada na semântica será fútil” (CHOMSKY, 1957, p. 15). Não obstante, é precisamente a semântica que justifica a estranheza dessa sentença, embora não pelos motivos que Chomsky alegou. Na verdade, o falante de inglês em questão pôde construir (3b) porque dispunha de um instrumento para produzir sentenças, e com certeza ele produzira diversas instâncias de sentenças semelhantes às de (1e) e (2) antes de produzir as de (3). Dizendo de outro modo, só se pode produzir (3) depois de se ter o instrumento que surgiu do processo de produção de sentenças como as de (1)-(2).

Vejamos o que provoca a estranheza de (3a-b), partindo da versão portuguesa (3a). A despeito da opinião de Chomsky, essa estranheza se deve ao fato de que os seres do mundo designados pelos lexemas que compõem a língua não se inter-relacionam diretamente. O qualificativo verde só pode ser atribuído a seres dotados de corpo material, perceptíveis pelo sentido da visão, além de, no cérebro dos falantes, não haver conexão direta entre "verde" e a área dos conceitos abstratos. Como ideia é uma abstração, falar-se em "ideia verde" é um absurdo. Mesmo que existissem "ideias verdes", elas não poderiam ser incolores, pois o conceito de cor inclui o de verde; no cérebro, "verde" está diretamente conectado a "cor" em termos de inclusão, e a "incolor" numa relação de oposição polar. Em seguida, a ação de dormir só pode ser praticada por animais superiores (mamíferos?). Sendo "ideia" uma abstração, "dormir" não pode ser atribuído a ela. A ação de dormir pode ser tranquila, agitada, mas não furiosa. Fúria pressupõe uma certa consciência e, como sabemos, enquanto dorme, o animal está inconsciente. Enfim, a estranheza de (3) se deve ao fato de relacionar diretamente na língua coisas que no MA natural não estão relacionadas. Pelo fato de não estarem relacionadas diretamente nesse MA, geralmente não estão relacionadas de modo imediato no MA mental.

É bem verdade que se poderia dar outra interpretação aos itens lexicais de (3), o que, aliás, já foi feito. Por exemplo: verdes $=>$ imaturas; incolores $=>$ irrelevantes; dormem $=>$ estão na cabeça; furiosamente $=>$ fervilhando. Com isso teríamos (4).

(4) Ideias imaturas irrelevantes estão fervilhando na cabeça 
No entanto, (4) já é outra sentença. Não podemos analisar semanticamente uma sentença x partindo de uma sentença y. Além do mais, (3) só poderia ocorrer em situações formais, em que um linguista fabrica uma sentença para estudar. Ela jamais ocorreria em um ato de interação comunicativa normal que se dá entre os membros de P, em situações normais da vida, embora a sintaxe a preveja mecanicamente, o que faz dela uma sentença inativada. Ela só pôde ser formulada porque a língua adquire uma relativa autonomia diante do MA do qual emergiu.

Vejamos a morfologia derivacional. Uma vez que os membros de $\mathrm{P}$ introduziram o hábito de produzir palavras plurimorfêmicas como in.con.stitu.cion.al.ism.o, está aberto o caminho para produzir também *in.de.stitu.cion.al.ism.o, uma vez que os morfemas constitutivos de ambas têm as mesmas funções e ocorrem nas mesmas posições. Formas como *in.de.stitu.cion.al.ism.o ficam desativadas mental e societariamente, podendo ser ativadas se e quando se fizer necessário. Tanto que um ex-ministro usou a forma i.mex.í.vel, que muitos consideraram "errada". O que aconteceu foi apenas que o ex-ministro teve a coragem de ativá-la, coisa que as pessoas "cultas" não fazem, por estarem bloqueadas pelo normativismo gramáticoescolar. Enfim, a morfologia alarga enormemente o poder referencial da língua, vale dizer, sua autonomia relativa.

Até na fonologia podemos ver essa autonomia relativa. Alíngua portuguesa, por exemplo, tem 19 consoantes e 12 vogais, incluindo-se as vogais nasais. Entre as sílabas que esses 21 fonemas permitem formar, estão todas as que entram na formação das palavras do presente texto. Contudo, a gramática fonológica dessa língua permite formar sílabas ainda não ativadas, como é o caso de /flès/, exatamente paralela a/frès/, que ocorre na palavra "fresta". Que eu saiba,/flès/ ainda não ocorre em nenhuma palavra, mas se surgir algum tablete de chocolate com o nome "taflés", ninguém acharia estranho, como acharia uma forma como /split/. Isso significa que, mesmo incluindo formas não ativadas como *in.de.stitu.cion.al.ism.o, ainda não temos todas as palavras fonológicas possíveis da língua. Os padrões silábicos possíveis ainda não foram explorados em sua totalidade.

O fato é que, após formada como reflexo de aspectos do meio ambiente, a língua adquire uma autonomia relativa, autonomia gigantescamente grande. Essa autonomia relativa advém do alargamento referencial propiciado pela reutilização e reciclagem de recursos do léxico, da sintaxe, da morfologia e da 
fonologia. Esse gigantesco alargamento do poder expressivo dá a impressão de que Lé independente de MA ou, como alguns apregoam, de que MA é formado por L. Isso resulta de um equívoco, do fato de os defensores dessa visão se esquecerem de que originalmente L surgiu para falar de MA, como se pode comprovar ontogeneticamente a qualquer momento, e, como Ernst Haeckel já dissera, a ontogênese reproduz a filogênese. Só depois é que $L$ adquiriu uma autonomia relativa, mas, o simples fato de a autonomia ser relativa já indica que L está ligada a MA.

Se essa relação original entre L e MA for esquecida, ou conscientemente deixada de lado, caímos no que Adams (1991) chamou de "referente ausente". Ela estava falando dos consumidores de carne, que omitem o referente animal vivo que teve que ser assassinado para dar lugar à carne que eles degustam na mesa. Excluindo o referente, livram-se de coisas desagradáveis, como a ideia de se matar um animal, esfolá-lo, recortá-lo, inclusive com moscas revoando em volta. Eles simplesmente compram a carne "limpa" e embrulhada de modo asséptico no supermercado. Como ecofeminista, Carol Adams associa isso ao tratamento dado à mulher pelo homem. Eu não vou tratar dessa questão aqui.

A autonomia relativa da linguagem tem vantagens e desvantagens. Entre as vantagens, temos a possibilidade de se criarem poesia, ficção, enfim, a "criatividade" verbal em geral. Entre as desvantagens, temos a manipulação das palavras por pessoas inescrupulosas, como a maioria dos políticos que infestam nosso país. Para serem eleitos, prometem mundos e fundos. Quando se cobra isso deles após eleitos, dizem que não é bem assim, que as circunstâncias mudaram e assim por diante. As grandes firmas poluidoras também fazem uso desse estratagema em profusão. Nos seus anúncios, salientam o número de empregos que criaram, mas omitem o custo que sua atividade cobra do meio ambiente. $\mathrm{O}$ fato é que é preciso não nos esquecermos nunca de que $\mathrm{L}$ nasceu da interação dos membros de $\mathrm{P}$ em MA, o que implica que $\mathrm{L}$ traz a marca indelével de MA. É bem verdade que levar essa ligação a ferro e fogo seria uma atitude fascista, assim como achar que o mundo é construído pela linguagem pode levar a manipulações de L de consequências imprevisíveis, o que agradaria a qualquer ditadorzinho ou tiranete de plantão, do jaez de Hitler e Stalin. O ideal é uma relação dialética entre as duas posições, ou seja, a ênfase nas inter-relações.

A gramática gerativa encara essa autonomia relativa da linguagem diante do mundo abstratamente, sob a forma de recursividade. Trata-se do princípio do 
uso infinito de recursos finitos. Para ela, a língua é um sistema estático, independente do MA. Para a ecolinguística, Lé uma realidade dinâmica e está inextricavelmente ligada ao mundo (MAFFI, 2001, 2002). Examinemos essa disciplina mais de perto.

\section{Ecolinguística}

Ecolinguística é a disciplina que surgiu para integrar tudo que as disciplinas mencionadas anteriormente vinham fazendo parcelar e fragmentadamente. Ela é a ciência das relações entre língua e meio ambiente, e não apenas do MA social, como Haugen, Salzinger e, até certo ponto, Sapir haviam afirmado. Ela estuda não apenas as relações que se dão no interior do ecossistema maior, ou seja, entre $\mathrm{P}, \mathrm{T}$ e L. Ela se ocupa também das relações entre L e o cérebro/mente dos membros de $\mathrm{P}$ (MA mental), das relações que mantém com os membros de $\mathrm{P}$ organizados em T, ou seja, como comunidade (MA social), bem como das relações indiretas entre L e o mundo físico (MA natural). Enfim, ecolinguística é literalmente a disciplina que se ocupa das relações que se dão entre língua e meio ambiente. Para mais discussão sobre a novel disciplina, pode-se consultar Fill (1993), Mühlhäusler (2003) e Couto (2007).

Há uma série de equívocos em relação à ecolinguística. Um primeiro equívoco é achar que ela é o mesmo que a Hipótese Sapir-Whorf, como me disse um colega após palestra que proferi em uma universidade brasileira. Ora, sobretudo em sua versão radical, essa hipótese afirma justamente o contrário do que propõe a ecolinguística. Esta última aceita até certo ponto a versão moderada da hipótese de que a linguagem pode direcionar nosso modo de ver o mundo, mas apenas direcionar, não determinar. Portanto, o que há de comum entre ela e a referida hipótese é que uma pequena parte desta pode ser aceita por ela.

O segundo equívoco não é menos grave. Para algumas pessoas, a ciência das relações entre língua e meio ambiente seria desnecessária porque tudo que ela estuda já vem sendo estudado por outras ciências. Assim, o que ela se propõe estudar nas relações entre L e MA natural já seria estudado pela filosofia, sob rótulos como "referência", "designação" e outros. O que ela estuda nas relações entre L e MA mental já viria sendo investigado pelas neurociências, sobretudo a neurolinguística, além da psicolinguística, da psicologia, da neurofisiologia da linguagem, etc. Por fim, aquilo de que ela trata nas relações entre L e MA social estaria sendo estudado pela sociolinguística e pela análise do discurso, entre outras. A conclusão lógica é que a ecolinguística seria desnecessária. 
Visões equivocadas como essas podem ser facilmente refutadas. Tudo o que acaba de ser dito é verdade. No entanto, em um mundo de globalização, é necessário que tenhamos uma visão "global" da realidade que nos cerca. Um bom ponto de partida para se chegar a essa visão é a ecologia, que é parte da biologia, a ciência da vida, e cujos princípios estão em sintonia com a ciência moderna, sobretudo a teoria da relatividade e a teoria quântica (CAPRA, 2002a). Ela se preocupa com diversidade e inter-relações, não apenas com um sistema estático e desligado de tudo mais. Diante da degradação crescente do meio ambiente, inclusive ameaçando a continuidade da vida na face da terra, nada mais indicado do que cada cientista assumir uma postura de defesa dela. Uma maneira de o linguista entrar nessa luta é aderir aos postulados da ecologia, já assimilados pela ecolinguística. Nesse caso, ele pode continuar praticando sua ciência, mas cônscio de que seu objeto de estudo faz parte de uma cadeia maior. Ele pode continuar praticando análise do discurso, sociolinguística, psicolinguística, neurolinguística, filosofia da linguagem ou até sintaxe, mas de uma perspectiva unificadora, integradora. Só para dar um exemplo banal: o fonema/b/ não é uma coisa mas, semelhantemente ao que foi dito do conceito de gato acima, simplesmente um ponto em que uma série de relações se sobrepõem, no caso, oclusão, bilabialidade e sonoridade.

\section{Observações finais}

A diferença entre a nova postura e a anterior é que, adotando os princípios maiores da ecologia, cada cientista estará estudando sua árvore sem se esquecer de que ela faz parte de uma floresta. Estará adotando não a visão fragmentadora que se instaurou com a visão de mundo advinda da filosofia de Descartes e da mecânica de Newton. Pelo contrário, estará praticando um modo de fazer ciência proveniente dos achados da ecologia, da teoria da relatividade e da teoria quântica. Trata-se de outra maneira de ver o mundo, atitude que Einstein não se cansava de dizer que era necessária para entender os novos conhecimentos que a ciência conseguiu atingir. Ele e os demais criadores dessas ciências não se cansavam de dizer que, para entender a nova visão de mundo, era necessária uma nova postura. A linguagem existente era incapaz de expressar essa nova maneira de encará-lo (HEISENBERG, 1981).

Como vimos, as duas visões de mundo estão expressas nas figuras 4 e 5 . Da concepção da figura 4 , L pode ser considerada como uma projeção de $\mathrm{T}$, o 
que em princípio estaria em sintonia com os pressupostos da ecolinguística. $\mathrm{O}$ problema é que, nesse caso, L seria uma espécie de reflexo mecânico do mundo, independente da intervenção humana, como se vê na tradição metafísica e no primeiro Wittgenstein. Além do mais, essa concepção de linguagem a coloca entre nós e o mundo, o que significa que só teríamos acesso a ele por intermédio dela. Mesmo na interpretação de que $\mathrm{P}$ cria L (o indivíduo teria papel ativo no processo) para interagir com T, ela não é aceitável, pois inclusive nesse caso não teríamos acesso direto ao mundo. Esse acesso seria sempre mediado por $\mathrm{L}$, como na versão radical da Hipótese Sapir-Whorf e no chamado construtivismo radical (GLASERSFELD, 1989). De acordo com a concepção da figura 5, ao contrário, primeiro os membros de $\mathrm{P}$ teriam experiências (interação) com $\mathrm{o}$ mundo, o que incluiria as interações de seus membros entre si. Com isso, formarse-iam imagens mentais, que frequentemente evoluiriam para linguagem. Como salientara Sapir (1969), a língua é projeção do mundo, mas projeção filtrada pela totalidade dos membros da população (sociedade). Essa é a representação correta do que acontece na ontogênese e, provavelmente, deve ter acontecido na filogênese, como afirma Schaff (1974). Ambas concepções têm um lado positivo e um lado negativo. No entanto, o lado negativo da primeira tem um custo mais alto, levando-nos da ciência para o misticismo. O lado negativo da segunda tem um custo bem menor, por não fugir do terreno do falseável, embora possa ter consequências políticas imprevisíveis.

Por fim, o importante é que ambas têm um pouco de verdade. Aplicando à linguagem em geral o que Bakhtin (1981) dissera do signo, primeiro temos o reflexo do mundo na mente dos membros da comunidade. Em seguida, dá-se uma refração desse reflexo de volta ao mundo. Como o homem que veio do pó e ao pó voltará, também L nasce em $\mathrm{T}$ e a T se dirige.

\section{Referências bibliográficas}

ADAMS, Carol. Ecofeminism and the eating of animal. Hypatia 6,1, p. 125-145, 1991.

AMABIS, José M.; MARTHO, Gilberto R.Biologia das populações, genética, evolução e ecologia. 5. ed. São Paulo: Editora Moderna, 1995.

BAKHTIN, Mikhail. Marxismo e filosofia da linguagem. 2. ed. São Paulo: Hucitec, 1981. 
BANDURA, Albert. Principles of behavior modification. New York: Holt, Rinehart \& Winston, 1969.

BLOOMFIELD, Leonard. Language. New York: Holt, Rinehart \& Winston, 1933.

BROWN, Colin M.; HAGOORT, Peter; KUTAS, Mart. Postlexical integration processes in language comprehension: Evidence from brain-imaging research. In: Gazzaniga (org.), p. 881-895, 2000.

CAPRA, Fritjof. O tao da física. São Paulo: Cultrix, 2002.

CHOMSKY, Noam. Syntactic structures. 8. ed. Haia: Mouton, 1957.

CHOMSKY, Noam. Aspects of the theory of syntax. Cambridge: The MIT Press, 1965.

CHOMSKY, Noam. Knowledge of language. New York: Praeger, 1986.

CHOMSKY, Noam. Language and problems of knowledge: The Managua lectures. Cambridge: The MIT Press, 1988.

CHOMSKY, Noam. Chomsky no Brasil. Número especial de DELTA 13, 1997.

COULMAS, Florian. Sprache und Staat. Berlim: Walter de Gruyter, 1985.

COUTO, Hildo Honório do. Introdução ao estudo das línguas crioulas e pidgins. Brasília: Editora da UnB, 1996.

COUTO, Hildo Honório do. Sobre o conceito de comunidade surda. Revista de Estudos da Linguagem v. 3, p. 193-219, 2005.

COUTO, Hildo Honório do. Ecolinguística: estudo das relações entre língua e meio ambiente. Brasília: Thesaurus Editora, 2007.

DØØR, Jørgen; BANG, Jørgen Chr. Language, ecology and truth - dialogue and dialectics. In: Fill (org.): 17-25, 1996.

FILL, Alwin. Ökologie: Eine Einführung. Tübingen: Gunter Narr Verlag, 1993.

FRANÇA, Aniela Improta. Neurolinguística. Ciência hoje, v. 36, 21, p.20-25, 2005.

FRANÇOZO, Edson. Modelos conexionistas do processamento sintático. In: MAIA, Marcus; FINGER, Ingrid (Org.). Processamento da linguagem. Pelotas (RS): EDUCAT, 2005. p. 443-458.

GAZZANIGA, Michael S. (Org.). The new cognitive neurosciences. Cambridge: The MIT Press, 2000.

GLASERSFELD, Ernst von. Cognition, construction of knowledge, and teaching. Synthese 80,1, p. 121-140, 1989. 
GUMPERZ, John. Speech community. In: GIGLIOLI, Pier Paolo (Org.). Language and social context. Harmondsworth: Penguin Books, 1972. p. 219-231.

HAGÈGE, Claude. L'homme de paroles. Paris: Fayard, 1985.

HAIMAN, John. The iconicity of grammar: isomorphism and motivation. Language 56,3, p. 515-540, 1980.

HAUGEN, Einar. The ecology of language. Stanford: Stanford University Press: 1972. p. 325-339.

HEISENBERG, Werner. Física e filosofia. Brasília: Editora da Universidade de Brasília, 1981.

HELBIG, Gerhard. Geschichte der neueren Sprachwisseschaft. 2. ed. Hamburgo: Rowohlt, 1975.

KUHL, Patricia K. Language, mind, and brain: Experience alters perception. In: GAZZANIGA (Org.). p. 99-115, 2000.

LAMB, Sydney M. Neuro-cognitive structure in the interplay of language and thought. In: PÜTZ, Martin; VESPOOR, Marjolijn H. (Org.). Explorations in linguistic relativity. Amsterdam: Benjamins, 2000. p. 173-196.

LEVELT, Willem J. M. Introduction. In: GAZZANIGA (Org), p. 843-844, 2000. LEWIN, Kurt. A dynamic theory of personality. New York: McGraw-Hill, 1935. MAFFI, Luisa (Org.). On biocultural diversity: Linking laguage, knowledge, and the environment. Washington: Smithsonian Institution Press, 2001.

MAFFI, Luisa. Linguistic and biological diversity: The inextricable link. Disponível em: <www.terralingua.org>. Acesso em: 2002.

MANDELBAUM, David (Org.). Selected Writings of Edward Sapir in language, culture and personality. Berkeley: University of California Press, 1949. p. 89-103.

MELO, Fábio José Dantas de. Os ciganos calon de Mambaí: a sobrevivência de sua língua. Brasília: Thesaurus Editora, 2005.

MUFWENE, Salikoko. The ecology of language evolution. Cambridge: Cambridge University Press, 2001.

MÜHLHÄUSLER, Peter. Language of environment - Environment of language: A course in ecolinguistics. Londres: Battlebridge, 2003.

NAESS, Arne. Heidegger, postmodern theory and deep ecology. The trumpeter 14, 4, 1997. 
OGDEN, C. K.; RICHARDS, I. A. O significado de significado. Rio de Janeiro: Zahar Editores, 1972.

PARADIS, Michel. Language and thought in bilinguals. In: The sixth LACUS Forum. Columbia, S.C.: Hornbeam Press, 1980. p. 420-431.

PEIRCE, Charles Sanders. Semiótica e filosofia. São Paulo: Cultrix, 1972.

PINKER, Steven. Words and rules. New York: Perennial, 2000.

SALZINGER, Kurt. Ecolinguistics: A radical behavior theory approach to language behavior. In: AARONSON, Doris; RIEBER, Robert W. (Org.). Psycholinguistic research: Implications and applications. N. York: Erlbaum, 1979. p. 109-129.

SAPIR, Edward. Língua e ambiente. Linguística como ciência. Rio de Janeiro: Livraria Acadêmica, 1969. p. 43-62.

SAUSSURE, Ferdinand de. Curso de linguística geral. 5. ed. brasileira. São Paulo: Cultrix, 1973.

SCHAFF, Adam. Linguagem e conhecimento. Coimbra: Livraria Almedina, 1974.

SHARKEY, Noel. Fundamental issues for connectionist language processing. In: BROWN, Gillian; MALMKJAER, Kirsten; WILLIAMS, John (Org.). Performance and competence in second language acquisition. Cambridge: Cambridge University Press, 1996. p. 155-184.

TONNEAU, J. Sociologie économique. In: LEMONNYER, A. et al. Précis de sociologie. Marselha: Editions Publiroc, 1934. p. 93-147.

TANSLEY, Arthur G. The use and abuse of vegetational concepts and terms. Ecology 16,3, p. 284-307, 1935.

TRAMPE, Wilhelm. Ökologische Linguistik: Grundlagen einer ökologischen Wissenschafts- und Sprachtheorie. Opladen: Westdeutscher Verlag, 1990.

WEISGERBER, Leo. Die geschichtliche Kraft der deutschen Sprache. Düsseldorf: Pädagogischer Verlag Schwann, 1950. 